\title{
Article \\ Designing for the Environment: An Example of Multi-Criteria Analysis Used for Solar Hot Water System Selection
}

\author{
Agnieszka Żelazna (D) and Justyna Gołębiowska *(D) \\ Faculty of Environmental Engineering, Lublin University of Technology, 40B Nadbystrzycka Str., \\ 20-618 Lublin, Poland; a.zelazna@pollub.pl \\ * Correspondence: j.golebiowska@pollub.pl; Tel.: +48-8153-844-06
}

Citation: Żelazna, A.; Gołębiowska, J Designing for the Environment: An Example of Multi-Criteria Analysis Used for Solar Hot Water System Selection. Energies 2022, 15, 65. https://doi.org/10.3390/en15010065

Academic Editor: Jan Danielewicz

Received: 24 November 2021 Accepted: 20 December 2021 Published: 22 December 2021

Publisher's Note: MDPI stays neutral with regard to jurisdictional claims in published maps and institutional affiliations.

Copyright: (c) 2021 by the authors. Licensee MDPI, Basel, Switzerland. This article is an open access article distributed under the terms and conditions of the Creative Commons Attribution (CC BY) license (https:// creativecommons.org/licenses/by/ $4.0 /)$.

\begin{abstract}
In the European Union, the building sector accounts for more than $40 \%$ of final energy consumption, contributing to the deterioration of the quality of the environment. Among the various solutions that aim to reduce the negative environmental impact caused by the operation of buildings, solar hot water systems (SHW) are popular. The choice of a SHW system is associated with the comfort of use and the access to low-cost energy. The design guidelines include the technical parameters for system operation such as materials, dimensions, sizing and operation temperatures. However, the legitimacy of choosing a particular solution and the available technical parameters are key issues. In the presented study, a multi-criteria analysis was proposed as a basis for the proper selection of system parameters, e.g., collector type, solar tank volume. A model of the SHW system was used to calculate the possible solutions, ensuring the same comfort of usage for several design options. The analyzed model was then used for the calculation of three various indicators: Simple Payback Time (SPBT), Primary Energy consumption (PE) and IMPACT 2002+. The application of a multi-criteria analysis based on a Life Cycle Assessment allowed for beneficial solutions to be found from the point of view of economics, non-renewable resources and environmental protection.
\end{abstract}

Keywords: solar thermal energy; SHW system; multi-criteria analysis; SPBT; EPBT; primary energy; IMPACT 2002+; LCA; sustainable design

\section{Introduction}

At present, energy seems to be an essential element for living in a modern society. The change in our lifestyle observed in recent decades resulted in a significant increase in energy consumption, especially in the case of the electricity, but also in other forms such as heat, required to meet the rising housing needs [1-3]. The growing interest in new renewable technologies in recent years is caused by several issues, such as the depletion of fossil resources, necessity to reduce air pollution, response to the problem of global climate change and the social expectations in the field of raising living standards and the comfortable use of buildings $[4,5]$.

Among the renewable energy sources, solar energy is one of the most popular options because of several advantages. The energy supplied from the Sun to our planet exceeds the human demand for energy per year by about 8000 times. In theory, this means that the electromagnetic radiation from the Sun is able to cover the global demand for energy without the additional use of other energy sources. This energy is almost unlimited and does not cause environmental pollution, unlike conventional energy sources. The current level of radiation energy conversion technology does not allow the Sun's energy potential to be utilized in its entirety, which is why there is an aim to improve the devices that convert solar radiation into heat or electricity. An important disadvantage of using solar energy potential is that its absorption requires a large amount of space and favorable conditions [6]. The amount of solar radiation reaching the Earth's surface decreases with many factors, such as increasing cloudiness, as well as air contamination $[7,8]$. 
In the scientific literature of the last several years, an increasing interest in the subject of Life Cycle Assessment of solar systems can be observed; this applies to both technological processes and specific devices or materials. Various Life Cycle Impact Assessment (LCIA) methods are used. These include: Global Warming Potential (GWP), Cumulative Energy Demand (CED) and Eco-indicator 99. Some studies deal with the Life Cycle Assessment of solar energy installations and devices, including domestic hot water preparation systems and solar collectors themselves.

Over time, there have been significant advancements achieved by various research groups in the field of solar-thermal systems LCA [9-13]. Some of these include the LCA analysis of flat solar collectors [14] from raw material extraction, through production to obtaining a finished commercial product. The environmental load resulting from the transport of materials to the production plant was also taken into account. This research was based on the energy and ecological characteristics of the input products. The highest value of environmental load was connected with the following impact categories: primary energy consumption and acidification. The energy payback period, understood as the time needed to recover the energy expenditure incurred for the production of the collector, excluding the other elements and energy required for operation, was shorter than 1 year [14].

Another study [15] presented the Life Cycle Impact Assessment carried out for a solar heating installation located in Greece. The production stages of individual elements of the installation and their impact on the environment were considered. The system boundaries include the production of raw materials (steel, glass, copper, and aluminum), operation of the installation and final disposal. The installation consisted of a flat solar collector with a copper absorber $\left(4 \mathrm{~m}^{2}\right)$ and a domestic hot water tank with a capacity of $200 \mathrm{dm}^{3}$. An electric heater was an additional heat source. Studies showed that the system provided $1702 \mathrm{kWh}$ per year, with solar energy accounting for $58.8 \%$ of this value. An LCIA analysis was carried out using the Eco-indicator 99 method, which showed that the largest environmental impact came from the solar hot water tank. Moreover, the greatest environmental burden was connected with the following impact categories: soil acidification, smog production and impact on global warming.

An environmental analysis was also used for the assessment of the selective surface for flat-plate solar collectors, which was carried out using the following methods: CED, GHG (Greenhouse Gas Protocol method based on the set of characterization factors by Intergovernmental Panel for Climate Change IPCC GWP 100a) and Eco-indicator 99. The authors compared the conventional method of selective surface production with the latest production method-roll to roll (R2R).

Research showed that the annual energy demand for the production of $200,000 \mathrm{~m}^{2}$ of selective surface is equal 7.91 TJ. Additional research based on CED allowed the energy payback time for R2R production to be determined, which was only 3-4 days. Among the analyzed factors, copper has the greatest impact on the environment, as it also requires the highest amount of energy in the production of selective surfaces. The results of the analysis clearly showed that the production of the selective surface for flat-plate solar collectors with the conventional method was much more harmful to the environment than the production by means of the roll-to-roll method [16].

A study in Munich (temperate climate conditions) presented an analysis of the life cycle of two hot water preparation systems with glazed solar collectors and unglazed polypropylene collectors. The Eco-indicator 99 method was used to assess the entire life cycle. The main components of both systems were solar panels and a $300 \mathrm{dm}^{3}$ buffer tank. The glazed panel consisted of an outer aluminum frame, two layers of mineral wool, a copper absorber and a copper alloy absorber piping system. The whole construction was hermetically closed with $4 \mathrm{~mm}$ thick transparent glass. In contrast, the plastic collector considered in this study was a polypropylene strip $7 \mathrm{~mm}$ thick, $313 \mathrm{~mm}$ wide and of variable length, which allowed the panel to be modular. The duration of the operation of both installations was 10 years. For glazed solar collectors, the calculated index was 49.7 points, while for plastic collectors it was 18.7 points. The largest share here was the 
use of fossil fuels: $52 \%$ and $68 \%$, respectively. On the other hand, the GWP calculated over a period of 100 years was $1670.92 \mathrm{~kg} \mathrm{CO}_{2 \mathrm{eq}}$ for a glazed solar collector and $105.06 \mathrm{~kg}$ $\mathrm{CO}_{2 \mathrm{eq}}$ for a plastic collector. The economic payback time, in comparison to the natural gas boiler, is in the range 9-11 years / 8-13 years for the system with unglazed/glazed panels, respectively [17].

To conclude, it should be emphasized that the analyses carried out so far concern the production of materials, the entire life cycle of the installation or case studies [18-21]; however, attention is rarely paid to proper design parameters. In the literature, few research works address the topic of the life cycle of installations that operate under the temperate climatic conditions, such as the Polish climate, and relate to a long-term perspective. The present study significantly supplements the current state of knowledge due to the implementation of the selected design criteria into the analyzed model of life cycle.

\section{Materials and Methods}

In the current study, an attempt to conduct a holistic, multi-criteria analysis of a solar thermal system was presented in order to set the designer's guidelines and frames for correct system selection. A typical installation of solar hot water system (SHW), supported by an electric heater in the winter period was chosen as the subject of the analysis. The scheme of the typical solar installation is presented in Figure 1. The analysis included 6 variants of installations located in Central Europe (Poland, Łódź: $51.759247^{\circ} \mathrm{N}, 19.455982^{\circ} \mathrm{E}$ ), with orientation towards the south (azimuth $0^{\circ}$ ) and inclination of $40^{\circ}$. The daily domestic hot water demand was assumed at constant level of $180 \mathrm{~L}$. The characteristics of the technical parameters for different variants of installations are shown in Table 1. The aim of the modeling was to estimate the influence of selected design parameters (type of collector, piping and water tank capacity) on the economical, energetic and environmental aspects of SHW operation.

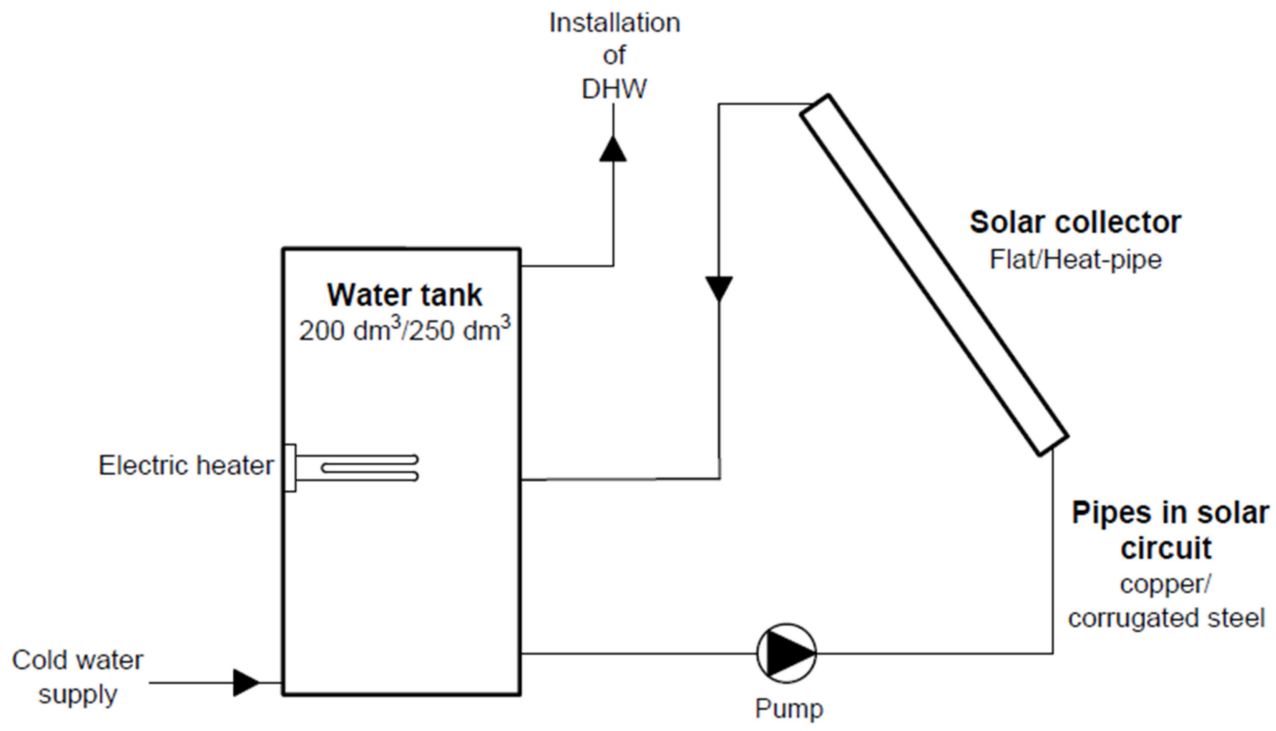

Figure 1. Scheme of the simulated installation. 
Table 1. Technical parameters of the analyzed system variants.

\begin{tabular}{|c|c|c|c|c|c|c|}
\hline $\begin{array}{l}\text { Variant of } \\
\text { Installation }\end{array}$ & Solar Collector & $\begin{array}{c}\text { Absorber } \\
\text { Area }\end{array}$ & Pipes & Water Tank & Solar Energy & $\begin{array}{c}\text { Annual } \\
\text { Efficiency }\end{array}$ \\
\hline- & - & $\mathrm{m}^{2}$ & - & $\mathrm{dm}^{3}$ & $\mathrm{kWh} / \mathrm{yr}$ & $\%$ \\
\hline Variant I & Flat-plate, CU absorber & 4.66 & Copper & 200 & 1602 & 30 \\
\hline Variant II & Flat-plate, CU absorber & 4.66 & Copper & 250 & 1627 & 30.5 \\
\hline Variant III & Flat-plate, CU absorber & 4.66 & Steel (corrugated) & 200 & 1576 & 29.5 \\
\hline Variant IV & Flat-plate, CU absorber & 4.66 & Steel (corrugated) & 250 & 1600 & 30 \\
\hline Variant V & Heat pipe & 4.29 & Copper & 200 & 1842 & 37.5 \\
\hline Variant VI & Heat pipe & 4.29 & Copper & 250 & 1865 & 37.9 \\
\hline Variant VII & Heat pipe & 4.29 & Steel (corrugated) & 200 & 1810 & 36.8 \\
\hline Variant VIII & Heat pipe & 4.29 & Steel (corrugated) & 250 & 1834 & 37.3 \\
\hline
\end{tabular}

The base scenario for comparison with the design options included an electric heater, while the annual electricity consumption equaled $2727 \mathrm{kWh}$. Modeling of solar energy gains was performed by using GetSolar software (Hottgenroth Software GmbH \& Co. KG, Germany), a popular tool using f-chart-based estimation of energy gains from SHW systems in a chosen location (Łódź, Poland), characterized by the total annual solar radiation of $3710.8 \mathrm{MJ} / \mathrm{m}^{2}$ and the average annual total insolation of $1560.4 \mathrm{~h}$.

The main inputs to the analysis include: solar irradiance on collector plane and ambient temperature data (from WetSyn weather data synthesis program integrated with GetSolar software), type of solar system (single, combined, etc.), collector parameters (including optical efficiency and collector area), heat losses, water tank volume, inclination and azimuth, mass flow of solar fluid, pipes length and pipes diameter. The more detailed description of the f-chart model can be found in [22].

A detailed inventory, based on cost of materials and energy consumption estimated for every variant of system, was then used for the detailed Life Cycle Assessment. Modeling of the life cycle was based on the use of SimaPro v. 8.0.5.13 software (PRE Consultans, Amersfoort, The Netherlands) and Ecoinvent v. 3 database (Ecoinvent Assoiation, Zurich, Switzerland), which was used for the description of unit processes. Life Cycle Impact Assessment was performed by means of the the IMPACT 2002+ and CED v. 3 methods.

The IMPACT 2002+ method allows for the assessment of environmental stress connected with the life cycle of the solar system. The indicator (expressed in points: Pt) links all types of inventory results throughout the fourteen midpoint categories into four main damage categories: Human Health, Ecosystem Quality, Climate Change and Resources. The higher the indicator calculated by using this method, the greater the environmental impact of the system [23]. The functional unit was $1 \mathrm{kWh}$ of energy generated by the system.

Cumulative Energy Demand (CED) method was used to estimate the total primary energy consumption (expressed in MJ) of the solar system throughout its entire lifetime, including the direct and indirect energy streams associated with the particular phases of life cycle [24].

For the validation of final results in CED, Monte Carlo statistical simulations (lognormal distribution) were implemented in order to compare the possible error between the achieved results.

In the multi-criteria analysis, the economic and environmental issues were discussed according to the following scheme. Firstly, Simple Payback Time (SPBT) was calculated for every variant of installation according to the definition, expressing the total cost of investment and operation divided by yearly savings [11].

In the next step, Energy Payback Time (EPBT) was calculated as a basis for technological foundations of the functioning of the system. EPBT was based on the CED results: in this case, statistical processing of data was a basis for the determination of the confidence interval. In the third part of evaluation, IMPACT 2002+ was calculated as an environmental criterion. The results obtained during the mentioned stages were then evaluated to indicate the most advantageous option with the use of the Weighted Sum Method. 


\section{Results}

In the following subsection, the results of the economic, energetic and environmental evaluation of the analyzed SHW systems are presented with special attention paid to the financial and energetic payback times, as well as to the environmental damage categories affected by the production and operation of the systems. All of the detailed calculations are finally used to evaluate the selected installation options based on the ratings awarded in the multi-criteria analysis.

\subsection{Solar Hot Water Systems: Economic Evaluation}

The economic evaluation of the SHW system in variants I-VIII was based on the on-line price catalogues and average market cost of installation, with the use of direct contact with the owners and investors. The data on the operation of the installation and service costs were obtained from the users of the installation in the form of an interview confirmed by billing documentation.

The pump operation cost was based on the measured energy consumption in a 3-year operation period of heat-pipe collector installation [11] and the price of energy in Poland in 2018 (0.5055 PLN/kWh recalculated to 0.1113 Euro/kWh) according to the Energy Regulatory Office [25].

According to the data presented in Table 2, the Simple Payback Time in the basic option (investment cost covered by the owner only) exceeds 11 years in all of the variants, assuming a constant price of electricity. However, while considering the popular support programs such as Prosument 2, the payback time may be shorter. In this case, financing the investment by taking up credit is a clear approach, which may worsen the presented results. In the case of the support programs financed by the local authorities, where the discount may reach $70 \%$, SPBT decreases by almost threefold to 4.1 years in the most effective options of installation.

Table 2. Results of economic evaluation for the analyzed system variants.

\begin{tabular}{cccccccc}
\hline $\begin{array}{c}\text { Variant of } \\
\text { Installation }\end{array}$ & $\begin{array}{c}\text { Investment } \\
\text { Cost }\end{array}$ & $\begin{array}{c}\text { Pump Operation } \\
\text { Cost }\end{array}$ & $\begin{array}{c}\text { Servicing/Utilization } \\
\text { Cost }\end{array}$ & Savings & SPBT $^{*}$ & SPBT $^{* *}$ & SPBT $^{* * *}$ \\
\hline- & Euro & Euro/yr & Euro & Euro/yr & Years & Years & Years \\
\hline Variant I & 1795.43 & 13.56 & 220.26 & 164.8 & 12.2 & 9.8 & 4.6 \\
Variant II & 1998.07 & 13.77 & 220.26 & 167.4 & 13.3 & 10.5 & 4.9 \\
Variant III & 1759.91 & 13.34 & 220.26 & 162.1 & 12.2 & 9.8 & 4.6 \\
Variant IV & 1962.56 & 13.54 & 220.26 & 164.6 & 13.3 & 10.6 \\
Variant V & 1871.53 & 15.59 & 220.26 & 189.5 & 11.0 & 8.8 & 4.9 \\
Variant VI & 2074.17 & 15.78 & 220.26 & 191.9 & 12.0 & 9.5 & 4.4 \\
Variant VII & 1836.01 & 15.32 & 220.26 & 186.2 & 11.0 & 8.8 & 4.1 \\
Variant VIII & 2038.66 & 15.52 & 220.26 & 188.7 & 12.0 & 9.5 & 4.4 \\
\hline
\end{tabular}

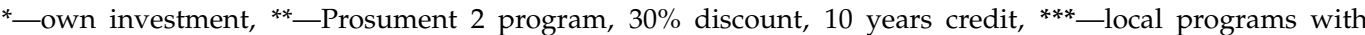
$70 \%$ discount.

\subsection{Solar Hot Water Systems: Energy Balance}

Energy balance of the SHW system was considered with the use of the CED method, as well as the calculation of the energy generated by the solar system. It is worth underlining that the predicted energy consumption in the 20-year operation period was included in the calculation, according to Figure 2. 


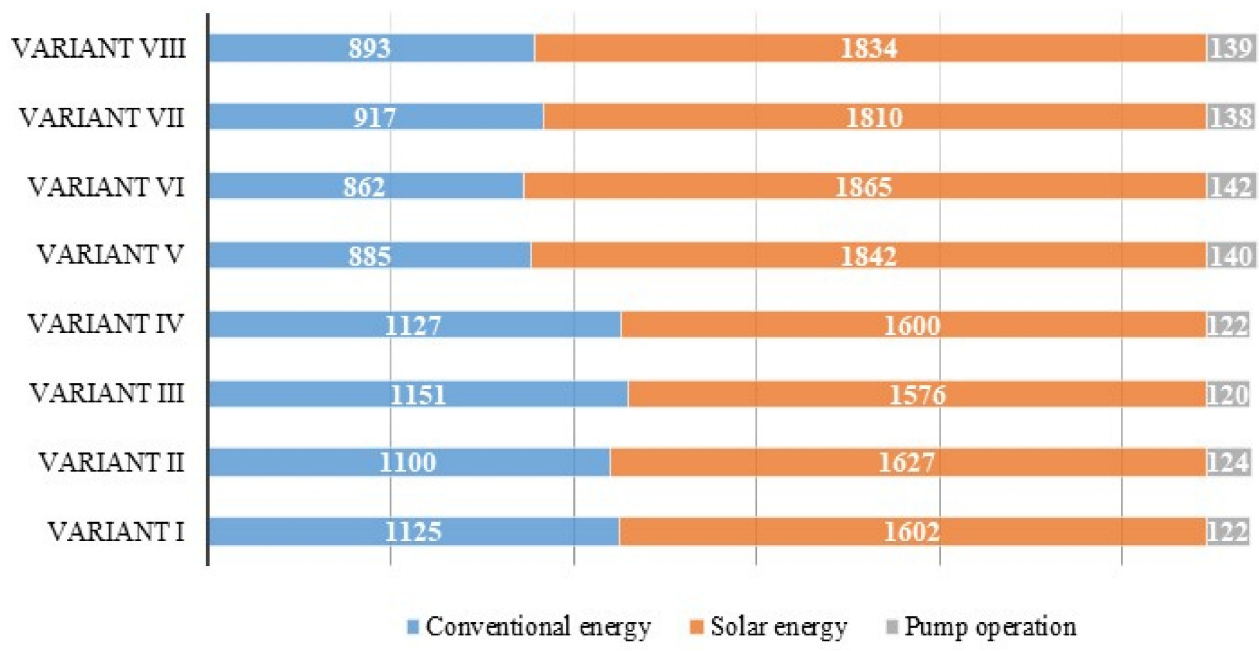

Figure 2. Energy balance of one-year operation of system according to the applied model.

The obtained EPBT results (Table 3) are higher than in some literature studies [17]. This may be caused by both the differences in solar irradiation, as well as the type of system and source of energy used for pumping. In all the considered cases, the EPBT indicator was significantly shorter than the predicted lifespan, assumed as 20 years.

Table 3. Results of energetic and economic evaluation.

\begin{tabular}{cccc}
\hline $\begin{array}{c}\text { Variant of } \\
\text { Installation }\end{array}$ & CED & Energy Generated & EPBT \\
\hline & MJ & MJ/yr & Years \\
\hline Variant I & $50,513.62$ & 5767.20 & 8.76 \\
Variant II & $51,545.74$ & 5857.20 & 8.80 \\
Variant III & $50,849.69$ & 5673.60 & 8.96 \\
Variant IV & $51,364.05$ & 5760.00 & 9.00 \\
Variant V & $53,830.63$ & 6631.20 & 8.12 \\
Variant VI & $54,819.90$ & 6714.00 & 8.17 \\
Variant VII & $54,038.12$ & 6516.00 & 8.29 \\
Variant VIII & $55,048.82$ & 6602.40 & 8.34 \\
\hline
\end{tabular}

The results of LCIA conducted using CED indicator were subjected to a sensitivity analysis by means of the Monte Carlo statistical method (Figure 3). All system inputs and outputs were successively changed in the frames of standard deviation in 1000 trials, which allowed the scale of possible error to be shown in the calculations. The confidence level was assumed as $95 \%$. In all the variants, the scale of possible error was similar, and the statistical distribution was positively skewed with a higher mean than the median in all analyzed cases.

\subsection{Solar Hot Water Systems: Environmental Impact Indicators}

The impact on the environment, considered as ecosystems, resources, human health and climate change, was assessed with the IMPACT2002+ method. The results of the impact assessment stage, recalculated to the functional unit ( $1 \mathrm{kWh}$ of energy generated by the system) are presented in Figure 4. The share analysis on the level of processes shows that the electricity used for pumping is the most influential process in the SHW system life cycle. Other important elements include solar collectors and water tanks due to the high consumption of materials. 


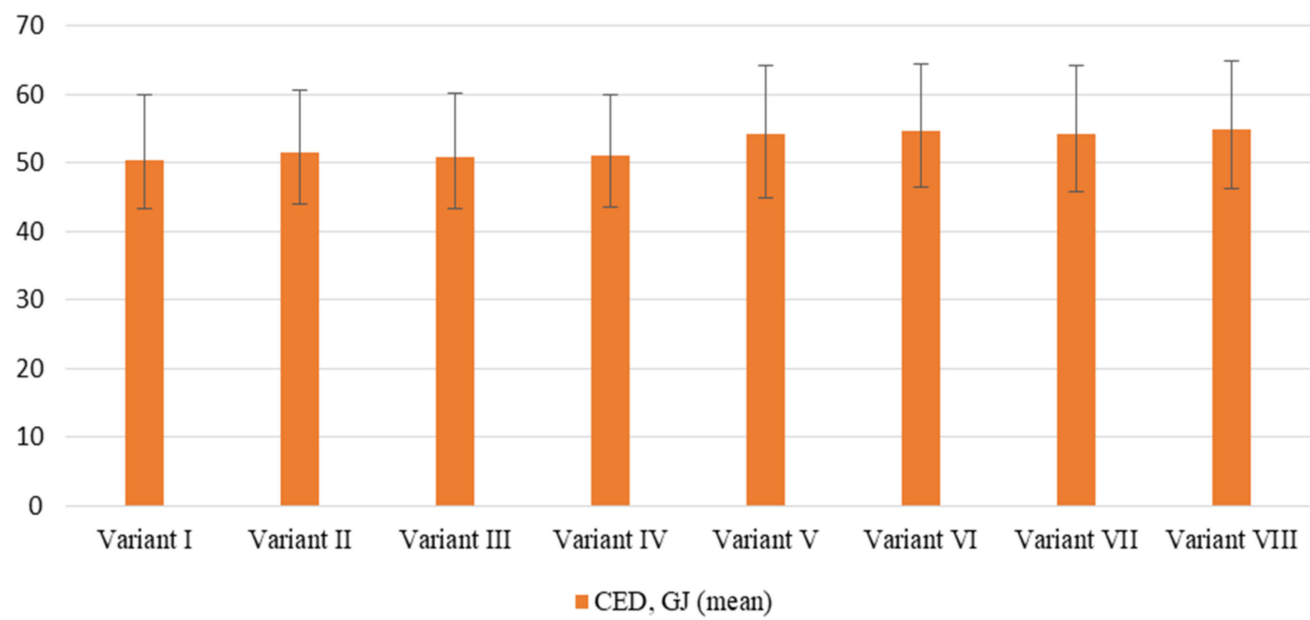

Figure 3. Results of CED calculation with the statistical error based on the Monte Carlo analysis.

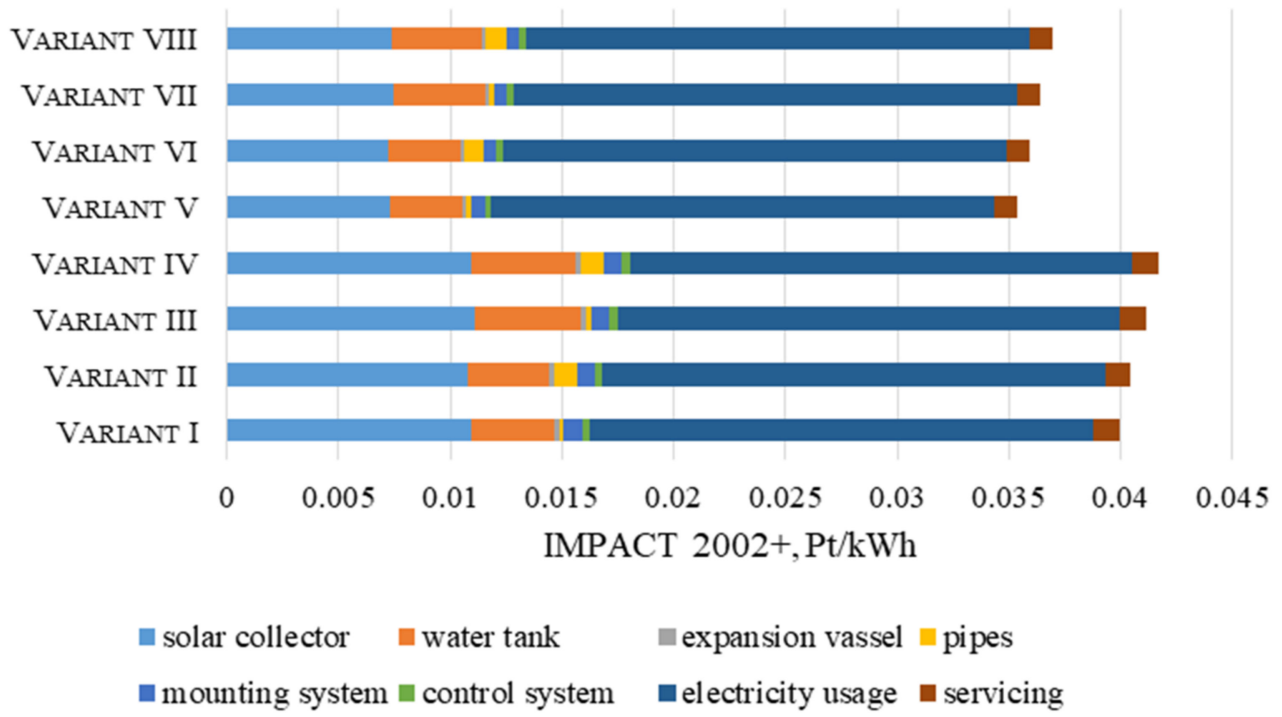

Figure 4. Results of IMPACT 2002+ calculation per functional unit, Pt/kWh.

According to the share analysis on the damage categories level, the results obtained for the analyzed systems are similar for Variants I-VIII, with the highest contribution from the Human health, Climate change and Resources categories. This is caused mostly by the similarities in construction and the supporting conventional energy used (Figure 5).

\subsection{Solar Hot Water Systems: Multi-Criteria Analysis}

The analysis performed in this study aimed to compare several alternatives of solar hot water system construction on the basis of SPBT, EPBT and IMPACT 2002+ indicators. Assuming equal weights for all the analyzed criteria, the MCA results were presented by means of the Weighted Sum Method indicator as a percentage of the difference between the actual and minimal parameter related to the difference between the maximal and minimal parameter (Table 4). 


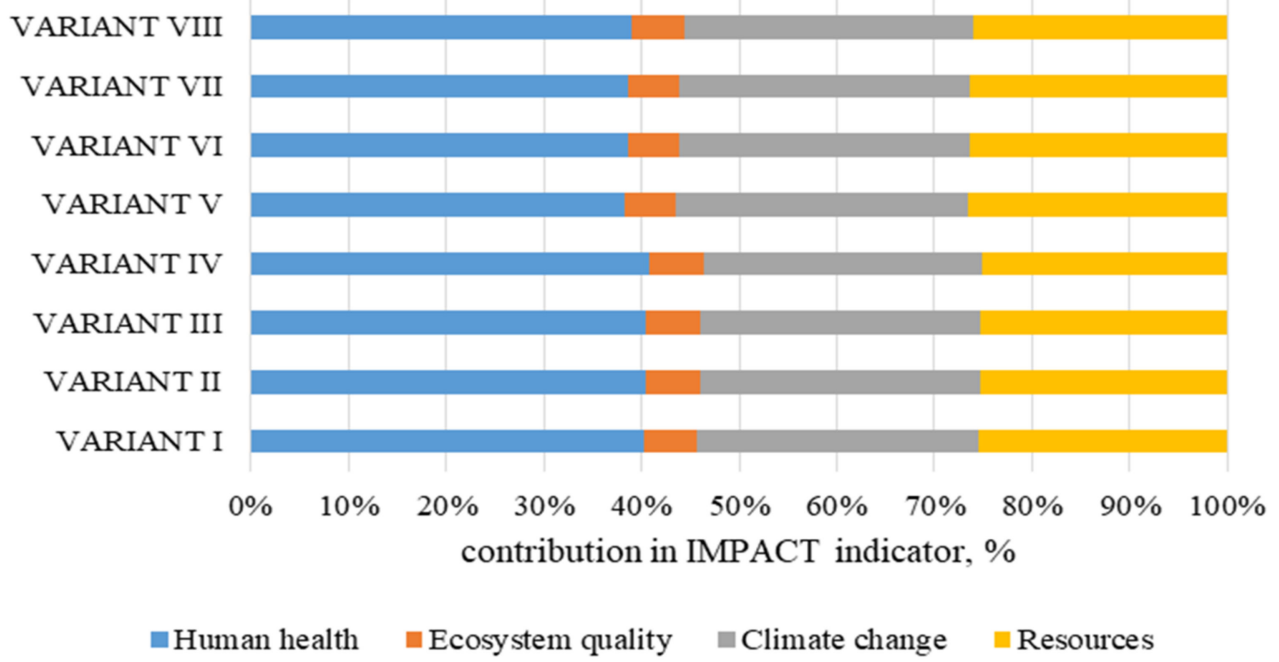

Figure 5. Share analysis of IMPACT2002+ indicator on damage category level.

Table 4. Results of multi-criteria evaluation.

\begin{tabular}{ccccc}
\hline $\begin{array}{c}\text { Variant of } \\
\text { Installation }\end{array}$ & SPBT & EPBT & IMPACT 2002+ & WSM Result \\
\hline - & Years & Years & Pt/kWh & \% \\
\hline Variant I & 4.6 & 8.8 & 0.040 & $68 \%$ \\
Variant II & 4.9 & 8.8 & 0.040 & $85 \%$ \\
Variant III & 4.6 & 9.0 & 0.041 & $83 \%$ \\
Variant IV & 4.9 & 9.0 & 0.042 & $100 \%$ \\
Variant V & 4.1 & 8.1 & 0.035 & $0 \%$ \\
Variant VI & 4.4 & 8.2 & 0.036 & $16 \%$ \\
Variant VII & 4.1 & 8.3 & 0.036 & $29 \%$ \\
Variant VIII & 4.4 & & 0.037 & \\
\hline
\end{tabular}

According to the data in Table 4, the best option is Variant $\mathrm{V}$ of installation, where all of the analyzed parameters were minimal due to the high efficiency of the system. Conversely, Variant IV can be assessed as the worst due to the longest payback periods and the highest environmental impact indicator. Following the specification of the analyzed systems, one can state that the most meaningful parameter is the type of solar collector. This contributed to approximately a $60 \%$ difference between systems (Variant I-IV vs. Variant V-VIII). The other analyzed parameters, such as water tank capacity (16-17\% difference), and pipe material (13-15\%) were also important. In turn, compared to the literature values, the analyzed solutions are characterized by higher payback times. This is connected with the method of analysis, e.g., covering the additional conventional energy spent on system operation, as well as various climate conditions.

\section{Conclusions}

According to the presented results, the most favorable solution included a heat-pipeevacuated tube collector, copper pipes and $200 \mathrm{dm}^{3}$ water tank. Although the selection of a higher-capacity tank led to the optimization of solar energy conversion efficiency, the increase in this parameter was not crucial for the conducted research. However, it should be underlined that the values of the calculated indicators are comparable for all cases. For example, the payback times for both energy and financial inputs differed by no more than 11 months. Therefore, the analyzed systems can be assessed as green solutions, significantly minimizing the environmental impact connected with conventional energy usage.

The multi-criteria analysis, covering several aspects of systems' life cycle, can be used as a tool for the optimization of their selection in the green designing process. More- 
over, the additional criteria used for sustainable designing can significantly improve the environmental balance of the analyzed technologies.

Author Contributions: Conceptualization, A.Ż.; methodology, A.Ż.; software, A.Ż. and J.G.; validation, A.Ż.; formal analysis, A.Ż. and J.G.; investigation, A.Ż.; resources, A.Ż.; data curation, A.Ż.; writing — original draft preparation, A.Ż.; writing —review and editing, A.Ż. and J.G.; supervision, A.Ż. and J.G.; project administration, A.Ż. and J.G. All authors have read and agreed to the published version of the manuscript.

Funding: The publication is supported from founds FD-20/IS-6/012 and FD-20/IS-6/042 granted by Faculty of Environmental Engineering, Lublin University of Technology.

Data Availability Statement: Not applicable.

Conflicts of Interest: The authors declare no conflict of interest.

\section{References}

1. Van Ruijven, B.J.; De Cian, E.; Wing, I.S. Amplification of future energy demand growth due to climate change. Nat. Commun. 2019, 10, 1-12. [CrossRef] [PubMed]

2. Jackson, R.B.; Le Quéré, C.; Andrew, R.M.; Canadell, J.G.; Korsbakken, J.I.; Liu, Z.; Peters, G.P.; Zheng, B. Global energy growth is outpacing decarbonization. Environ. Res. Lett. 2018, 13, 120401. [CrossRef]

3. Żelazna, A.; Gołębiowska, J.; Zdyb, A.; Pawłowski, A. A Hybrid vs. On-Grid Photovoltaic System: Multicriteria Analysis of Environmental, Economic, and Technical Aspects in Life Cycle Perspective. Energies 2020, 13, 3978. [CrossRef]

4. Asdrubali, F.; Baldinelli, G.; D'Alessandro, F.; Scrucca, F. Life cycle assessment of electricity production from renewable energies: Review and results harmonization. Renew. Sustain. Energy Rev. 2015, 42, 1113-1122. [CrossRef]

5. Żelazna, A.; Zdyb, A.; Pawłowski, A. The influence of selected factors on PV systems environmental indicators. Annu. Set Environ. Prot. 2016, 18, 722-732.

6. Olczak, P.; Matuszewska, D.; Zabagło, J. The Comparison of Solar Energy Gaining Effectiveness between Flat Plate Collectors and Evacuated Tube Collectors with Heat Pipe: Case Study. Energies 2020, 13, 1829. [CrossRef]

7. Mularczyk, A.; Husa, B. Rozwój i perspektywy energii solarnej w Polsce i Województwie Śląskim. Zesz. Naukowe. Organ. Zarzadzanie Politech. Śląka 2015, 86, 361-377. (In Polish)

8. Olczak, P. The comparison of solar installation heat gains and SHW simulation results-case study. Polityka Energetyczna 2020, 23, 41-54. (In Polish) [CrossRef]

9. Hang, Y.; Qu, M.; Zhao, F. Economic and environmental life cycle analysis of solar hot water systems in the United States. Energy Build. 2012, 45, 181-188. [CrossRef]

10. Souliotis, M.; Arnaoutakis, N.; Panaras, G.; Kavga, A.; Papaefthimiou, S. Experimental study and Life Cycle Assessment (LCA) of Hybrid Photovoltaic/Thermal (PV/T) solar systems for domestic applications. Renew. Energy 2018, 126, 708-723. [CrossRef]

11. Saint, R.M.; Pomponi, F.; Currie, J.I. A method for a cradle-to-cradle life cycle assessment of integrated collector-storage solar water heaters. IOP Conf. Ser. Mater. Sci. Eng. 2019, 556, 012061. [CrossRef]

12. Kalogirou, S. Thermal performance, economic and environmental life cycle analysis of thermosiphon solar water heaters. Sol. Energy 2009, 83, 39-48. [CrossRef]

13. Żelazna, A. The influence of collector type on emission indicators in solar systems life cycle assessment. Annu. Set Environ. Prot. 2013, 15, 258-271.

14. Głuszek, A.; Magiera, J.; Neupauer, K. Analiza cyklu życia (LCA) cieczowego kolektora słonecznego. Inżynieria Apar. Chem. 2010, 49, 35-36. (In Polish)

15. Koroneos, C.J.; Nanaki, E.A. Life cycle environmental impact assessment of solar water heater. J. Clean. Prod. 2012, 37, 154-161. [CrossRef]

16. Altun-Ciftcioglu, G.A.; Gokulu, O.; Kardigan, F.; Kardigan, M.A.N. Life cycle (LCA) of solar selective surface produced by continuous process and solar flat collectors. Sol. Energy 2016, 135, 284-290. [CrossRef]

17. Comodi, G.; Bevilacqua, M.; Caresana, F.; Paciarotti, C.; Pelagalli, L.; Venella, P. Life cycle assessment and energy-CO2-economic payback analyses of renewable domestic hot water systems with unglazed and glazed solar thermal panels. Appl. Energy 2016, 164, 944-955. [CrossRef]

18. Milousi, M.; Souliotis, M.; Arampatzis, G.; Papaefthimiou, S. Evaluating the Environmental Performance of Solar Energy Systems Through a Combined Life Cycle Assessment and Cost Analysis. Sustainability 2019, 11, 2539. [CrossRef]

19. Mahmud, M.A.P.; Huda, N.; Farjana, S.H.; Lang, C. Environmental Impacts of Solar-Photovoltaic and Solar-Thermal Systems with Life-Cycle Assessment. Energies 2018, 11, 2346. [CrossRef]

20. De Laborderie, A.; Puech, C.; Adra, N.; Blanc, I.; Beloin-Saint-Pierre, D.; Padey, P.; Payet, J.; Sie, M.; Jacquin, P. Environmental Impacts of Solar Thermal Systems with Life Cycle Assessment. In The World Renewable Energy Congress; Linköping University Electronic Press: Linkoping, Sweden, 2011; pp. 8-13. Available online: https://hal-mines-paristech.archives-ouvertes.fr/hal-00 668172/document (accessed on 10 May 2021). 
21. Barbir, F. Fuel Cell Applications. In PEM Fuel Cells, Theory and Practice, 2nd ed.; Barbir, F., Ed.; Academic Press: Cambridge, MA, USA, 2013; pp. 373-434.

22. Astudillo-Flores, M.; Zalamea-Leon, E.; Pelaez-Samaniego, A.B.E.M.; Calle-Siguencia, J. Modelling of solar thermal energy for household use in equatorial latitude by using the F-Chart model. Renew. Energy Power Qual. J. 2021, 19, 269-275. [CrossRef]

23. Jolliet, O.; Margni, M.; Charles, R.; Humbert, S.; Payet, J.; Rebitzer, G.; Rosenbaum, R. IMPACT 2002+: A New Life Cycle Impact Assessment Methodology. Int. J. LCA 2003, 8, 324-330. [CrossRef]

24. Frischknecht, R.; Wyss, F.; Knöpfel, S.B.; Lützkendorf, T.; Balouktsi, M. Cumulative energy demand in LCA: The energy harvested approach. Int. J. Life Cycle Assess. 2015, 20, 957-969. [CrossRef]

25. Energy Regulatory Office. Available online: https://www.ure.gov.pl/en (accessed on 4 May 2021). 